\title{
A Atualidade do Liberalismo Político de Bobbio na Época do Liberalismo Econômico e do Populismo Autoritário
}

\begin{abstract}
Giuseppe Tosi
Doutor em filosofia pela Universidade de Pádua (1999). Pós-Doutorado em Teoria e História dos Direitos Humanos pela Universidade de Florença (2006) e de Camerino (2012). Professor titular do Departamento de Filosofia da UFPB. Ex-Coordenador do Núcleo de Cidadania e Direitos Humanos. Professor dos Programas de Pós-Graduação em Direitos Humanos, Cidadania e Políticas Públicas e em Filosofia da UFPB. Líder do Grupo de Pesquisa "Teoria e História dos Direitos Humanos e da Democracia". Áreas de interesse: Filosofia Política, Teoria e História dos Direitos Humanos e da Democracia, Educação em Direitos Humanos. Autores: Aristóteles, Bartolomé de Las Casas, Norberto Bobbio. http://lattes.cnpq.br/1332521470619712.

http://orcid.org/0000-0001-9321-2552 pinuccio@uol.com.br
\end{abstract}

RESUMO

Após a queda do muro de Berlim, os intelectuais liberais manifestaram a cauta esperança de que o encerramento do período histórico da guerra fria abriria uma nova era de expansão do Estado Democrático de Direito no mundo. Esta esperança realizou-se em parte (a terceira onda de Huntington), mas está hoje em crise tanto nos regimes democráticos consolidados quanto nos novos regimes políticos que saíram de regimes autoritários. Os países que não experimentaram historicamente a democracia liberal, como a China e a Rússia, são governados por regimes de liberalismo econômico e de autoritarismo político; as primaveras árabes, na maioria dos casos, não resultaram em regimes democráticos, mas em guerras civis e/ou ditaduras militares; e nos países de tradição democrática, como a Europa e os Estados Unidos, a ideologia política que mais cresce é o populismo de extrema direta. Bobbio viria com preocupação este movimento, porque era favorável a um liberalismo político, mas mantinha severas restrições ao liberalismo econômico, e era também um crítico do populismo, que considerava uma forma de democracia plebiscitária com rasgos autoritários. Diante deste contexto, queremos debater a atualidade do liberalismo bobbiano, na esperança de que não estamos assistindo aos "últimos capítulos" de uma longa e gloriosa tradição. Faremos isso analisando três diferentes tipos de liberalismo (político, econômico e social), e três diferentes tipos de democracia (elitista, plebiscitária e participativa), relacionando-as na procura da "melhor forma de governo". Finalmente teceremos algumas breves considerações sobre a situação política brasileira à luz desses princípios.

Palavras-chave: Liberalismo político. Liberalismo econômico. Democracia. Populismo. Autoritarismo.

THE ACTUALITY OF BOBBIO'S POLITICAL LIBERALISM IN THE ERA OF ECONOMIC LIBERALISM AND AUTHORITARIAN POPULISM

\section{ABSTRACT}

After the fall of the Berlin Wall, liberal intellectuals expressed the cautious hope that the closing of the historical period of the Cold War would open a new era of expansion of the Democratic Rule of Law in the world. This hope has been fulfilled in part (the third wave of Huntington), but is now in crisis both in the consolidated democratic regimes and in the new political regimes that have left authoritarian regimes. Countries that have not historically experienced liberal democracy, such as China and Russia, are governed by regimes of economic liberalism and political authoritarianism; the Arabian springs, in most cases, did not result in democratic regimes, but in civil wars and/or military dictatorships; and in countries of democratic tradition such as Europe and the United States, the political ideology that grows most is extreme right populism. Bobbio would be concerned about this movement, because it was in favour of political liberalism, but maintained severe restrictions on economic liberalism, and was also a critic of populism, which he considered a form of plebiscitary democracy with authoritarian features. Given this context, we want to discuss the timeliness of Bobbio's liberalism, in the hope that we are not watching the "last chapters" of a long and glorious tradition. We will do this by analysing three different types of liberalism (political, economic and social), and three different types of democracy (elitist, plebiscitary and participatory), linking them to one another in the quest for "the best form of government". Finally, we will make some considerations about the Brazilian political situation in this context.

Keywords: Political liberalism. Economic liberalism. Democracy. Populism. Authoritarianism.

1 Introdução. 2 Três tipos de liberalismo. 2.1 Liberalismo Político: procedimentalismo e individualismo. 2.2 Liberalismo econômico, neoliberalismo ou "liberismo". 2.3 O Liberalismo social. 3 Três tipos de democracia. 3.1 A democracia representativa/elitista. 3.2 Democracia plebiscitária. 3.3 Democracia participativa. 4 Liberalismos e democracias. 5 Conclusões provisórias sobre o Brasil. 6 Referências. 


\section{INTRODUÇÃO}

Após a queda do muro de Berlim e a consequente crise do comunismo soviético (1989/1991), Norberto Bobbio e outros intelectuais liberais manifestaram a cauta esperança de que o encerramento do período histórico da guerra fria abriria uma nova era de expansão do Estado Democrático de Direito no mundo. Esta esperança (que não se confundia com a tese do fim da história de Fukuyama) realizou-se em parte: houve efetivamente uma internacionalização do Estado Democrático de Direito em algumas áreas do mundo como o Leste Europeu e a América Latina, que encerrou o trágico período das ditaduras militares: a "terceira onda" como a chamou Samuel Huntington (1994). Este panorama, no entanto, está mudando rapidamente.

Os países que não experimentaram historicamente a democracia, como a China e a Rússia, são governados por regimes de liberalismo econômico (embora com um forte controle estatal) e de autoritarismo político; as primaveras árabes, na maioria dos casos, não resultaram em regimes democráticos, mas em guerras civis e/ou ditaduras militares; e nos países de mais longa tradição democrática, como a Europa e os Estados Unidos, a ideologia política que mais cresce é o populismo de direita ou de extrema direta (BENOIST, 2017).

Os regimes autoritários, como na China e na Rússia, estão desafiando as democracias ocidentais em nome de uma superioridade ética e política de seus modelos autoritários diante das fragilidades e ineficiências das democracias liberais, que não conseguem dar conta dos processos de globalização econômica, política e social.

Está espalhando-se entre os cientistas político um forte pessimismo sobre as sortes da democracia liberal e a percepção de uma crise generalizada da democracia liberal (BRENNAN, 2017; LEVITSKY-ZIBLATT, 2018; CASTELLS, 2018). Poucos são os analistas que discordam. O principal dele é Steven Pinker (2018a,b), o defensor otimista do "novo iluminismo".

A democracia sofre duas ameaças para a sua sobrevivência: de um lado um elitismo tecnocrático, que defende não o liberalismo político, mas o liberalismo econômico; do outro lado, como reação a esta perda de controle do "povo" sobre a política, a resposta populista.

Afirma Yascha Mounk em O povo contra a democracia (2019):

A maioria dos cientistas políticos há muito considera o liberalismo e a democracia como complementares. Embora reconhecessem que os direitos individuais e a vontade popular nem sempre andam juntos, eles se aferravam à crença de que era esse o seu destino. Nos casos em que o liberalismo e a democracia caminham lado a lado, assim se diz, eles formam um amálgama particularmente estável, resiliente e coerente.

Mas quando as opiniões do povo tendem a ser iliberais e as preferências das elites se tornam antidemocráticas, liberalismo e democracia colidem. A democracia liberal, essa mistura única de direitos individuais e governo popular que há muito tem caracterizado a maioria dos governos na América do Norte e na Europa Ocidental, está se desmantelando. Em seu lugar, presenciamos a ascensão da democracia iliberal, ou democracia sem direitos, e do liberalismo antidemocrático, ou direitos sem democracia (p. 24).

Bobbio veria com preocupação este movimento porque era favorável a um liberalismo político, mas mantinha severas restrições ao liberalismo econômico (que os italianos chamam de liberismo), e era também um crítico do populismo, que considerava uma forma de democracia plebiscitária com rasgos autoritários. 


\section{Democracia}

Humanos e

Diante deste contexto, queremos debater neste ensaio a atualidade do liberalismo bobbiano, na esperança de não estarmos assistindo aos "últimos capítulos" de uma longa e gloriosa tradição, mas à sua continuidade.

Faremos isso apresentando três diferentes tipos de liberalismo (político, econômico e social), e três diferentes tipos de democracia (elitista, plebiscitária e participativa), relacionando-as entre si na procura da "melhor forma de governo". Finalmente teceremos algumas breves considerações sobre a situação política brasileira nesse contexto. ${ }^{1}$

\section{TRÊS TIPOS DE LIBERALISMO}

Vamos começar traçando brevemente as características principais dos diferentes tipos de liberalismos segundo Bobbio.

\subsection{Liberalismo Político: procedimentalismo e individualismo}

Bobbio defendeu uma concepção procedimentalista (democracia como regras do jogo) e individualista da democracia e dos direitos humanos como uma das características da democracia dos modernos contra o organicismo dos antigos, que, segundo ele, continua presente na política moderna a partir da filosofia romântica alemã até chegar ao totalitarismo nacional-socialista:

A filosofia política dos antigos não é predominantemente uma filosofia individualista, e muito menos atomizante. A sua inspiração dominante é a que é bem expressa na tese aristotélica do homem originariamente animal social que vive, desde o nascimento, em uma sociedade natural como a família. Esta ideia está na base da teoria organicista que teve longa vida no pensamento político ocidental e contribuiu para manter vivo o conceito de povo como um todo superior às partes até chegar à filosofia romântica alemã. Desta, que é o exato oposto da filosofia utilitarista surgida nos mesmos anos na Inglaterra, nasceram tanto o volkgeist da escola histórica alemã quanto a totalidade ética de Hegel, descendo até a volksgemeinschaft [comunidade nacional] de triste memória, não tão distante nos anos para que possa ser esquecida, que representou o desafio extremo a qualquer ideia de governo livre fundado sobre o princípio da dignidade e responsabilidade individual (BOBBIO, 2000a, p. 378-379).

Segundo Bobbio, o modelo organicista, por meio da filosofia romântica alemã e a sua exaltação do povo (Volks) organicamente entendido, chega a influenciar o totalitarismo nacional-socialista. Por isso, Bobbio (2000a) sugere "abandonar" o conceito de povo e de soberania popular:

Independentemente do pensamento romântico e neo-romântico, a ideia de soberania do povo teve origem, e foi mantida viva, a partir da oposição à soberania do príncipe. Hoje, que essa oposição não tem mais razão de existir, já que tendemos a não reconhecer outro princípio de legitimação além daquele que vem de baixo - exceto em alguns regimes teocráticos, que a consciência civil contemporânea considera resíduos do passado - também o conceito de soberania popular poderia ser tranquilamente abandonado (p. 379).

Bobbio vincula o conceito de povo não a um território, a uma história e a uma cultura tudo o que a "filosofia romântica alemã" queria -, mas à ideia de cidadania, entendida como gozo dos direitos humanos fundamentais e da reciprocidade entre direitos e deveres.

Não vou analisar nesse artigo as consequências da pandemia sobre os regimes democráticos, tema que mereceria uma outra discussão. 
"Povo" não é apenas um conceito ambíguo, precisamente porque não existe senão como metáfora um todo chamado "povo", distinto dos indivíduos que o compõem, mas é também um conceito enganoso. [...] Na democracia moderna, o soberano não é o povo, mas são todos os cidadãos. O povo é uma abstração, cômoda, mas também, como dissemos, falaciosa; os indivíduos, com seus defeitos e seus interesses, são uma realidade. Não é por acaso que como fundamento da democracia moderna estão as Declarações dos Direitos do Homem e do Cidadão, desconhecidas da democracia dos antigos (BOBBIO, 2000a, p. 379).

Este alerta para os perigos e as ambiguidades do conceito de "povo" chega ao ponto de propor a sua "eliminação" do léxico político para defender uma concepção individualista e liberal de democracia. Trata-se de uma postura bastante radical. Se eliminássemos o conceito de "povo", haveria um vazio em quase todas as constituições do mundo que encontram a origem do poder político justamente neste conceito: "Todo poder emana do povo, que o exerce por meio de representantes eleitos, ou diretamente, nos termos desta Constituição", afirma o artigo 1, §1 da Constituição Brasileira de 1988. Ainda que possa parecer um conceito "retórico", ele é um conceito limite, polissêmico, mas que não pode ser eliminado.

Entendemos, no entanto, que não é essa a intenção de Bobbio; ao contrário, ele quer determinar o seu significado de maneira mais precisa, vinculando-o ao conjunto de cidadãos que têm direitos políticos. Bobbio assume aqui uma concepção ao mesmo tempo liberal e elitista de democracia: liberal porque individualista, elitista porque representativa. Retoma, assim, temas recorrentes na crítica de Joseph Schumpeter aos conceitos "clássicos" de democracia (na verdade, à democracia de Rousseau): "vontade geral", "bem comum" e "soberania popular", que determinam uma hipostatização do "povo" como entidade unitária (SCHUMPETER, 1961).

O preocupante renascimento do populismo mostra a atualidade das preocupações de Bobbio. Hoje, o populismo, que era considerado um fenômeno latino-americano, é a doutrina e o movimento político que mais cresce no Ocidente, sobretudo na Europa e nos Estados Unidos, as democracias mais antigas e (aparentemente) mais consolidadas do planeta. ${ }^{2}$

\subsection{Liberalismo econômico, neoliberalismo ou "liberismo"}

Uma segunda forma de liberalismo é o liberalismo econômico, ou neoliberalismo ou liberismo defendidos por filósofos, como Ludwig Von Mises e Alfred Hayek, e economistas, como Milton Friedman da Escola de Chicago, preocupados com a liberdade econômica e sem um compromisso efetivo com as liberdades políticas e muito menos com a democracia (MERQUIOR, 1991, p. 188-196). ${ }^{3}$

\footnotetext{
Não parece suficiente rebater o populismo com os argumentos de uma visão de cidadania mais universal e cosmopolita desvinculada dos laços de sangue, território e de cultura, porque o populismo se fundamenta sobre sentimentos de pertença social, de comunidade, de grupo, de desconfiança para com o "outro", de medo para com o diferente, em suma, de uma identidade forjada numa relação negativa com a alteridade. Omnis determinatio, negatio é um princípio não somente lógico, mas ético-político. $\mathrm{O}$ "povo" enquanto entidade simbólica reaparece com toda a sua força no populismo. $\mathrm{O}$ fenômeno é muito complexo e merece uma reflexão à parte, que não podemos aqui desenvolver (LACLAU, 2008; PANIZZA, 2009; MOUFFE, 2017, 2019).

3 Merquior afirma que: "Quanto a Hayek, Bobbio o ataca por causa da sua tacitamente cíclica ideia de história - seu ingênuo dualismo de boas e más fases (boas quando o Estado se retira; más sempre que cresce). Diferentemente de Rawls, o neocontratualismo de Bobbio desafia abertamente os neoliberais conservadores" (1991, p. 218).
} 


\section{Humanos e \\ Democracia}

Bobbio (1997), em $O$ futuro da democracia, dedica um capítulo (Liberalismo velho $e$ novo) aos diferentes tipos de liberalismos enquanto ideologia política pluralista e diversificada; mas afirma que há dois tipos fundamentais, o econômico e o político, ${ }^{4}$ e que "há relações evidentes entre as duas teorias", por exemplo, na concepção negativa do Estado:

Característica da doutrina liberal econômico-política é uma concepção negativa do estado, reduzido a puro instrumento de realização dos fins individuais, e por contraste uma concepção positiva do não-estado, entendido como a esfera das relações nas quais o indivíduo em relação com os outros indivíduos forma, explicita e aperfeiçoa a própria personalidade (BOBBIO, 1997, p. 130).

Bobbio admite, no entanto, que as duas concepções são independentes e distintas, por exemplo, com relação ao socialismo e ao Estado do bem-estar social. O liberalismo político, na sua polêmica com o comunismo stalinista, reivindica as liberdades políticas e os direitos humanos não como valores burgueses, mas como valores universais:

Até poucos anos atrás, foi, sobretudo o liberalismo político que conservou a sua carga polêmica contra a destruição dos direitos do homem feita pelo stalinismo e bateu-se para contestar a tese segundo a qual os direitos do homem, nascidos em seguida das lutas do terceiro estado contra as monarquias absolutas, são direitos voltados para a defesa dos interesses da burguesia e, portanto não universalmente válidos (mas agora também a tese do nascimento exclusivamente burguês destes direitos foi historicamente refutada). São duas faces que se olham, mas que também podem não se olhar, na medida em que têm dois campos de observação diversos (BOBBIO, 1997, p. 117).

Após a queda do muro de Berlim e a expansão do neoliberalismo econômico, porém, o ataque dirige-se não mais contra o comunismo, mas contra a socialdemocracia.

Desde há alguns anos, porém, é o liberalismo econômico, ou liberismo, que ergueu a cabeça. Seu alvo não é tanto o coletivismo dos países em que os partidos comunistas assumiram o poder, quanto o Estado assistencial, isto é, o experimento socialdemocrático. Num certo sentido, o ataque contra o sistema soviético é dado como favas contadas. 0 que agora excita o espírito agressivo dos novos liberais é o efeito, considerado desastroso, das políticas keynesianas adotadas pelos estados economicamente e politicamente mais avançados, especialmente sob o impulso dos partidos socialdemocrático ou trabaIhistas (BOBBIO, 1997, p. 117).

Bobbio é um liberal, defensor do liberalismo político e não do liberalismo econômico, que entende como uma ameaça à democracia; citando a obra de Hayek ( $O$ caminho da servidão), Bobbio manifesta a sua preocupação e o seu dissenso:

\footnotetext{
4 Bobbio admite também um terceiro tipo de liberalismo, o ético, que considera como um pressuposto dos outros dois tipos e que define assim: "Por liberalismo ético entende-se a doutrina que coloca em primeiro lugar na escala de valores o indivíduo, consequentemente a liberdade individual, no duplo sentido de liberdade negativa e de liberdade positiva. Tanto a exigência de liberdade econômica quanto a exigência de liberdade política são consequências práticas, traduzíveis em regras e instituições, do primado axiológico do indivíduo". É possível definir este liberalismo como libertarianismo, que se fundamenta em um individualismo exacerbado que mantém pontos de contatos com o anarquismo.
} 
Pode-se descrever sinteticamente este despertar do liberalismo através da seguinte progressão (ou regressão) histórica: a ofensiva dos liberais voltou-se historicamente contra o socialismo, seu natural adversário na versão coletivista (que é, de resto, a mais autêntica); nestes últimos anos, voltou-se também contra o estado do bem-estar, isto é, contra a versão atenuada (segundo uma parte da esquerda também falsificada) do socialismo; agora é atacada a democracia, pura e simplesmente. A insídia é grave. Não está em jogo apenas o estado do bem-estar, quer dizer, o grande compromisso histórico entre o movimento operário e o capitalismo maduro, mas a própria democracia, quer dizer, o outro grande compromisso histórico precedente entre o tradicional privilégio da propriedade e o mundo do trabalho organizado, do qual nasce direta ou indiretamente a democracia moderna (através do sufrágio universal, da formação dos partidos de massa, etc.) (BOBBIO, 1997, p. 126, grifos do autor).

Há uma diferença substantiva entre liberais e liberistas quando se trata de enfrentar o ideário democrático, segundo Bobbio.

\subsection{O Liberalismo social}

Há uma terceira forma de liberalismo, sobretudo a partir do século 20, do tipo social, de autores como Keynes, Rawls e Bobbio. Guilherme Merquior (1991, p. 210-219) considera Bobbio um "liberal de esquerda", que defende a igualdade e um liberalismo social. Trata-se de um Estado Democrático de Direito que não garanta somente os direitos civis e políticos, mas também os direitos econômicos e sociais; dentro dos limites do sistema capitalista. Em última instância é o mercado que decide, mas o Estado pode intervir regulamentando o mercado e equalizando as condições dos cidadãos por meio de uma política de igualdade de oportunidades.

Bobbio, ao enfrentar historicamente o tema da relação entre liberalismo e socialismo na filosofia política dos séculos 19 e 20, mostra como os dois termos foram considerados, durante muito tempo e por muitos intérpretes, inconciliáveis, mas que houve também uma tentativa de conciliação.

O autor escreve a respeito:

O socialismo liberal partiu da conviç̧ão de que os dois "ismos" não constituem em absoluto uma antítese, um oximoro e por isso a sua integração prática deveria ser entendi$\mathrm{da}$, nesse caso, como uma síntese, definida hegelianamente como o terceiro momento de uma antítese, negada e superada. Aliás, o socialismo foi concebido como um natural desenvolvimento histórico do liberalismo no processo de emancipação da humanidade; daquele processo que se inscrevia na teoria do progresso e da história como história da liberdade. De um modo mais esquemático depois da emancipação política, que fora obra da Revolução Francesa, viria a emancipação econômica. Afinal, à Revolução Francesa, por sua vez, não precedera, através da Reforma e o processo de secularização que a ela se seguiu, a emancipação religiosa? (BOBBIO, 2000b, p. 364).

E continua com certo otimismo:

As primeiras duas formas de emancipação tiveram sucesso. A terceira mostrou-se bem mais difícil de realizar. Marx viu claramente o primado do poder econômico sobre os outros poderes, da base constituída exatamente pelas relações econômicas, em relação à superestrutura ideológica e política. Mas o remédio que propunha, ou que os movimen- 


\section{Humanos e \\ Democracia}

tos políticos que dele derivaram tentaram realizar, teve o efeito perverso que hoje temos diante dos olhos. Foi exatamente este efeito perverso que ressuscitou nos últimos anos 0 ideal do socialismo liberal (BOBBIO, 2000b, p. 365).

Bobbio assim define a relação entre socialismo e liberalismo:

Acredito que seja possível afirmar que o encontro entre liberalismo e socialismo tenha ocorrido historicamente através de dois diferentes caminhos: do liberalismo ou libertarismo em direção ao socialismo, entendido como complemento da democracia puramente liberal; do socialismo em direção ao liberalismo, como condição sine qua non de um socialismo que não seja iliberal. Como integração do segundo ao primeiro, como recuperação do primeiro em relação ao segundo (BOBBIO, 2000b, p. 365).

Liberalismo social e socialismo liberal encontram-se, assim, mesmo partindo de tradições e pressupostos diferentes, mas não excludentes: do individualismo um e do homem como ser social e político o outro; movimentos que Bobbio insere em um esquema progressivo bastante linear, apesar de estar consciente das incompatibilidades histórica e teóricas em favor de uma possível "integração prática".

Em O Futuro da Democracia, na sua crítica ao neoliberalismo, Bobbio reafirma que

O pensamento liberal continua a renascer, inclusive sob formas capazes de chocar pelo seu caráter regressivo, e de muitos pontos de vista ostensivamente reacionário (não se pode negar a intenção punitiva que assume a luta pelo desmantelamento do Estado assistencial, dirigida contra os que quiseram alçar demais a cabeça), porque está fundado sobre uma concepção filosófica da qual, agrade ou não, nasceu o mundo moderno: a concepção individualista da sociedade e da história. Uma concepção com a qual, no meu modo de ver, a esquerda, com a exceção de algumas formas de anarquismo, jamais fez seriamente um acerto de contas, e da qual não pode prescindir nenhum projeto que vise a libertação, a uma sempre maior libertação (de quem, se não do indivíduo?) (BOBBIO, 1997, p. 127).

O individualismo está na base do contratualismo moderno, do pacto social entre indivíduos livres e iguais que vivem em um hipotético estado de natureza:

O contratualismo moderno nasce da derrubada de uma concepção holística ou orgânica da sociedade (a concepção segundo a qual, de Aristóteles a Hegel, o todo é superior às partes), nasce da ideia de que o ponto de partida de todo projeto social de libertação é o indivíduo singular com suas paixões (a serem dirigidas ou domadas), com seus interesses (a serem regulados e coordenados), com suas necessidades (a serem satisfeitas ou reprimidas) (BOBBIO, 1997, p. 127).

O autor lança a proposta de um novo contratualismo, de um novo contrato social que compatibilize o individualismo liberal com o socialismo:

Em poucas palavras, trata-se de ver se, partindo da mesma concepção individualista da sociedade, que é irrenunciável, e adotando os mesmos instrumentos, estamos em condições de contrapor ao neocontratualismo dos liberais um projeto de contrato social diverso, que inclua em suas cláusulas um princípio de justiça distributiva e, portanto, seja compatível com a tradição teórica e prática do socialismo (BOBBIO, 1997, p. 127).

Feitas essas distinções sobre os diferentes tipos de liberalismos, passamos agora a analisar a democracia nas suas várias formas. 


\section{TRÊS TIPOS DE DEMOCRACIA}

\subsection{A democracia representativa/elitista}

A primeira característica da democracia moderna é que o poder soberano não é exercido diretamente, mas por intermédio dos representantes, pelo menos, por três motivos.

Um primeiro motivo refere-se às dimensões territoriais e administrativas dos Estados modernos, que se constituem a partir do século 16 , centralizando e unificando as fragmentações da Idade Média. O tamanho impede a participação direta dos cidadãos, como acontecia na assembleia ateniense, e obriga a recorrer aos representantes; portanto, a uma forma indireta de participação dos cidadãos. Neste contexto, o que foi decisivo para a afirmação da democracia foi a luta pelo sufrágio universal, ou seja, para a ampliação da representação, que perpassou todo o século 19 e parte do 20 e criou as democracias de massa contemporâneas, superando as democracias censitárias e elitistas posteriores às revoluções burguesas. Esta foi a luta dos socialismos, dos feminismos e de outros movimentos populares e de esquerda. A representação introduz na democracia o elemento da "classe política".

Um segundo motivo é relativo à complexidade das sociedades modernas, que exigem uma competência que os cidadãos não possuem. Não é mais possível, como na ekklesia grega, levantar a mão e aprovar ou rejeitar com um sim ou com um não uma proposta apresentada pelo líder ou pelo demagogo, ou é possível somente em alguns casos, não como política cotidiana. Introduz-se aqui outro elemento: a burocracia e a tecnocracia, que desafiam a competência do "povo" para governar. ${ }^{5}$

Um terceiro motivo deve-se ao pluralismo, que põe em dúvida a ideia de um bem comum ou do bem supremo da nação como um todo; há um pluralismo de interesses e ideológico sobre as diferentes concepções morais ou éticas de vida, concepções religiosas e doutrinas políticas. Vivemos sempre mais, como dizia Max Weber, em uma sociedade caracterizada por um "politeísmo de valores". Isto coloca em dúvida a ideia do "povo" como uma unidade que possui uma "vontade geral" que tende para o "bem comum", como pensava Rousseau.

A democracia representativa é uma forma de elitismo. A teoria das elites foi elaborada entre o final do século 19 e o início do 20 por dois sociólogos italianos, Vilfredo Pareto (18481923) e Gaetano Mosca (1858-1941), e um cientista político alemão, naturalizado italiano: Robert Michels (1876-1936) (BOBBIO, 2002; HOLLANDA, 2011; TOSI; GUIMARÃES, 2020). Os elitistas afirmam que em todos os regimes políticos, inclusive naqueles democráticos, nunca é o "povo" que governa, mas são sempre "elites": econômicas, políticas, sociais, religiosas, tecnológicas.

Os elitistas inserem-se na tradição do realismo político inaugurado em tempos modernos por Maquiavel e se apresentam como fundadores de uma "ciência política", a partir da qual fazem uma crítica às ideologias e às utopias (sobretudo marxistas) (PORTINARO, 2007).

O que se discute para o futuro é a possibilidade de uma democracia direta por meio de instrumentos de participação eletrônicos, virtuais, utilizando a internet e as outras redes telemáticas; mas é ainda uma discussão a ser feita. Ver LEVY, 2010a, 2010b; LEMOS, 2010. 


\section{Humanos e \\ Democracia}

Entre as definições de elites, a mais abrangente é aquela dada por Gaetano Mosca, em 1896, na obra Elementos de Ciência Política, citada no Dicionário de Política (1998) de Bobbio no verbete sobre elitismo por ele escrito:

Em todas as sociedades [...] existem duas classes de pessoas: as dos governantes e as dos governados. A primeira, que é sempre a menos numerosa, assume todas as funções públicas, monopoliza o poder e goza as vantagens que a ele estão anexas; enquanto que a segunda, mais numerosa, é dirigida e regulada pela primeira, de modo mais ou menos legal ou de modo mais ou menos arbitrário e violento, fornecendo a ela, ao menos aparentemente, os meios materiais de subsistência e os que são necessários à vitalidade do organismo político (MOSCA apud BOBBIO, 1998, p. 390).

Em nenhum sistema e em nenhuma época histórica, afirmam os elitistas - desde as organizações sociais e políticas mais primitivas até as civilizações mais avançadas e cultas -, nunca foi o povo quem governou, mas sempre um grupo restrito de elites (Pareto), uma oligarquia (Michels) ou uma classe política dirigente (Mosca).

Bobbio propõe uma leitura não "ideológica" e mais "científica" da teoria das elites na sua versão democrática, já presente in nuce, senão em Pareto, em Michels e, sobretudo, na doutrina da classe política de Mosca (BOBBIO, 1998, p. 387). Bobbio defende uma concepção elitista da democracia, que não seria propriamente "o poder do povo, pelo povo, e para o povo", qualquer que seja o sentido que se queira dar a esta fórmula; mas o tipo de governo em que "o povo" não governa diretamente, mas escolhe quem vai governá-lo.

Bobbio interpreta esta vertente democrática do elitismo "não tanto como a negação de existência de regimes democráticos, mas como uma redefinição que terminou por tornar-se preponderante na hodierna ciência política da Democracia"; ou seja, uma visão realista da "democracia como ela é", e não idealista de "como ela deveria ser". Bobbio insere-se, assim, entre os autores que se inspiraram na doutrina do elitismo democrático, como o cientista político Robert Dahl (1997), o filósofo do direito Hans Kelsen (2000) e o economista austríaco Joseph Schumpeter (1961). Segundo Bobbio, citando Schumpeter, "o que é a característica de um governo democrático não é a ausência de elites, mas a presença de muitas elites em concorrência entre si para a conquista do voto popular" (BOBBIO, 1997, p. 27).

A democracia diferencia-se (para melhor) dos outros regimes políticos porque permite o pluralismo, a competição e um recrutamento e uma "circulação das elites" (segundo a fórmula de Pareto) de maneira mais rápida e ampla. Assim, o elemento elitista é algo de inevitável em qualquer tipo de democracia mais ou menos forte. Dependendo dos tipos de governo e da qualidade da democracia, depende também e, sobretudo, da qualidade das suas elites políticas e classes dirigentes.

Para Schumpeter (1961), a democracia é o melhor sistema de governo não porque é o governo do povo, ou a expressão da soberania popular, que é mais um "mito político" do que uma realidade, mas porque permite um processo mais amplo de seleção e de recrutamento das elites políticas, incluindo nelas os representantes das classes tradicionalmente excluídas pelos regimes aristocráticos ou oligárquicos (SCHUMPETER, 1961, p. 339).

Bobbio (1997) cita, com aprovação, Schumpeter: 
Mas desde que parti de uma definição predominantemente procedimental da democracia, não se pode esquecer que um dos impulsionadores desta interpretação [elitista], Joseph Schumpeter, acertou em cheio quando sustentou que a característica de um governo democrático não é a ausência de elites, mas a presença de muitas elites em concorrência entre si para a conquista do voto popular (p. 27).

O autor menciona um "elitista italiano" que diferencia os regimes democráticos dos autocráticos pela existência, respectivamente, de "elites que se propõem" (elitismo democrático) e de elites que "se impõem" (elitismo autocrático) (BOBBIO, 2002, p. 280). Segundo Portinaro (2008), a concepção de democracia em Bobbio deve muito às doutrinas democráticas do tipo elitista:

Na história das doutrinas políticas do século XX, Bobbio está destinado a permanecer primariamente pela sua contribuição à doutrina procedimental da democracia, ou seja, àquela teoria que encontra os seus máximos expoentes em Kelsen e Schumpeter. Trata-se antes de tudo de uma concepção que se insere na grande família das teorias empíricas da democracia competitiva: o seu realismo, em particular o coloca entre os elitistas democráticos (p. 108. Tradução do autor).

Nesta perspectiva, as sociedades modernas são por demais complexas para poder ser governadas pelo "povo". Elas exigem uma "classe política" e uma classe de técnicos e cientistas que possuam conhecimentos suficientes para administrar uma máquina sempre mais diversificada. Se as elites do passado foram as aristocracias guerreiras e sacerdotais, as elites modernas são os técnicos e burocratas (Max Weber) (TOSI; GUIMARÃES, 2020).

A democracia é também o regime político que permite a existência dos conflitos, que não reprime, mas administra, que garante o pluralismo ideológico e de interesses, porque é no conflito social, na luta de classe, na competição política que se forjam as elites políticas; portanto, o conflito é, de certa forma, benéfico e indispensável; porém deve ser resolvido de maneira não violenta, ou com o uso de violência legítima do Estado de direito por meio das instituições e dos procedimentos estabelecidos convencionalmente.

Bobbio afirma que jamais esqueceu o ensinamento de Karl Popper (em A Sociedade Aberta e seus Inimigos, 2006), segundo o qual a democracia é o regime de governo em que o competidor não é considerado um inimigo a ser destruído, mas um adversário que, amanhã, pode se tornar governante, sem derramamento de sangue (sine effusione sanguinis) (BOBBIO, 1997, p. 39).

Essa concepção contrapõe-se a outra teoria da democracia que tem em Rousseau o seu principal inspirador e que Bobbio define como plebiscitária.

\subsection{Democracia plebiscitária}

A democracia direta moderna surgiu como reação à democracia representativa, com o intuito de alargar os espaços de cidadania a todas as esferas de decisão possíveis, procurando superar, assim, a dicotomia entre "povo" e "classe política", o distanciamento entre o "poder soberano do povo" e a alienação deste poder nas mãos de um grupo de representantes. Bobbio, porém, faz uma distinção entre democracia direta e democracia participativa.

A democracia direta, entendida como alternativa à democracia representativa, encontra seus fundamentos na crítica de Rousseau à representação: 


\section{Humanos e \\ Democracia}

Parto de uma constatação sobre a qual podemos estar todos de acordo: a exigência, tão frequente nos últimos anos, de maior democracia exprime-se como exigência de que a democracia representativa seja ladeada ou mesmo substituída pela democracia direta. Tal exigência não é nova: já a havia feito, como se sabe, o pai da democracia moderna, Jean-Jacques Rousseau, quando afirmou que "a soberania não pode ser representada" e, portanto, "o povo inglês acredita ser livre, mas se engana redondamente; só o é durante a eleição dos membros do parlamento; uma vez eleitos estes, ele volta a ser escravo, não é mais nada" (BOBBIO, 1997, p. 41).

Rousseau é o filósofo da liberdade entendida como autonomia plena do sujeito, que obedece somente à lei que ele mesmo se deu, e por isso é crítico da representação enquanto a liberdade é inalienável; por outro lado, Rousseau assume uma concepção monolítica ou monista do poder que põe em risco a liberdade.

No Contrato Social, as cláusulas que compõem o contrato reduzem-se a uma só:

A alienação total de cada associado, com todos os seus direitos, à comunidade toda, porque, em primeiro lugar, cada um, dando-se completamente, a condição é igual para todos, e sendo a condição igual para todos, ninguém se interessa em torná-la onerosa para os demais (ROUSSEAU, 1983, p. 32).

O conceito central que sustenta toda a argumentação é o de "vontade geral", uma "entidade metafísica" que não pode ser empiricamente identificada nem com a vontade da maioria tampouco mesmo com a vontade de todos (ROUSSEAU, 1983, p. 46-47), e é definida por Rousseau como inalienável, indivisível e infalível (ROUSSEAU, 1983, p. 44). A respeito disso, afirma Bobbio (1997):

Se por democracia direta se entende literalmente a participação de todos os cidadãos em todas as decisões a eles pertinentes, a proposta é insensata. [...] $\mathrm{O}$ indivíduo rousseauniano conclamado a participar de manhã à noite para exercer os seus deveres de cidadão não seria o homem total, mas o cidadão total (como foi chamado com evidentes intenções polêmicas por Dahrendorf). $\mathrm{E}$, bem vistas as coisas, o cidadão total nada mais é que a outra face igualmente ameaçadora do Estado total. Não por acaso, a democracia rousseauniana foi freqüentemente interpretada como democracia totalitária em polêmica com a democracia liberal (p. 54-55).

Com efeito, as características do poder soberano de Rousseau são muito próximas das do poder soberano de Hobbes: absoluto, indivisível e irresistível, assim como a vontade geral de Rousseau é indivisível, inalienável, infalível. Ambas as teorias não admitem limites jurídicos à soberania, como afirma o próprio Rousseau (1983):

Baseando-se nesta ideia [de que o objeto das leis é sempre geral], vê-se logo que não se deve mais perguntar a quem cabe fazer as leis, pois são atos da vontade geral, nem se o príncipe está acima das leis, visto que é membro do Estado; ou se a lei pode ser injusta, pois ninguém é injusto consigo mesmo, ou como pode ser livre e estar sujeito às leis, desde que estas não passam de registros nas nossas vontades (p. 55). 
Não é difícil ver como as características dessa democracia, que Bobbio define como "plebiscitária", encontram-se em algumas formações históricas como a demagogia, o populismo, e, no limite, os totalitarismos (BARZOTTO, 2003, p. 85-130). É este o perigo que Bobbio (1997) teme: em uma democracia plebiscitária o poder é monocrático, enquanto na democracia dos modernos é policrático:

O que significa então dizer que a democracia dos modernos deve fazer as contas com o pluralismo? Significa dizer que a democracia de um estado moderno nada mais pode ser que uma democracia pluralista. [...] A teoria democrática toma em consideração o poder autocrático, isto é, o poder que parte do alto, e sustenta que o remédio contra este tipo de poder só pode ser o poder que vem de baixo. A teoria pluralista toma em consideração o poder monocrático, isto é, o poder concentrado numa única mão, e sustenta que o remédio contra este tipo de poder é o poder distribuído (p. 60).

\subsection{Democracia participativa}

Segundo Bobbio, nas sociedades modernas não é possível nem desejável a transição de uma democracia representativa para uma democracia direta. Isto se deve não somente às dimensões e complexidades dos Estados modernos, mas também e, sobretudo, à necessidade de salvaguardar o pluralismo, as liberdades e garantias individuais e a livre-manifestação do conflito e do dissenso social.

Quando, porém, a democracia direta é entendida como complementação à democracia representativa, que Bobbio define como democracia participativa, não somente é possível, mas necessário, para evitar os perigos do elitismo: a separação das elites dos cidadãos, a apatia política, a cidadania passiva e todos os fenômenos bem conhecidos que provocam a "cri$\mathrm{se}^{\prime \prime}$ da democracia representativa.

Para Bobbio (1997),

Democracia representativa e democracia direta não são dois sistemas alternativos (no sentido de que onde existe uma não pode existir a outra), mas são dois sistemas que se podem integrar reciprocamente. Com uma fórmula sintética, pode-se dizer que num sistema de democracia integral as duas formas de democracia são ambas necessárias, mas não são consideradas em si mesmas suficientes (p. 52).

A participação dos cidadãos na vida política é algo, para Bobbio, extremamente salutar e necessária para corrigir os vícios da representação que tendem a concentrar o poder numa elite econômica, política e social. Aliás, Bobbio (1997) afirma que seria preciso não somente a democratização do Estado, mas também da sociedade:

Percebemos que uma coisa é a democratização do Estado (ocorrida com a instituição dos parlamentos), outra coisa é a democratização da sociedade, donde ser perfeitamente possível existir um Estado democrático numa sociedade em que a maior parte das instituições - da família à escola, da empresa à gestão dos serviços públicos - não são governadas democraticamente (p. 55).

A partir desta premissa, Bobbio lança o critério de que para uma sociedade ser democrática não é suficiente saber "quem vota", mas "onde se vota", abrindo perspectivas para uma participação política e social que tem a função de contrabalançar a sua concepção elitista da democracia. 


\section{Humanos e \\ Democracia}

No caso brasileiro, a Constituição de 1988 introduziu uma série de instrumentos de participação popular nos três poderes que permite uma efetiva participação dos cidadãos na vida política do país (LYRA, 2006, 2014). São instrumentos que favorecem uma maior efetividade ou eficácia na instituição das políticas públicas em direitos humanos, e um maior controle da população sobre o governo, procurando diminuir as formas de corrupção, ou seja, de uso da coisa pública para fins privados. ${ }^{6}$

\section{LIBERALISMOS E DEMOCRACIAS}

Se relacionarmos as três formas de liberalismo - o político, o econômico e o social com as três formas de democracia - representativa/elitista, plebiscitária e participativa -, teremos várias possibilidades, entre elas a que pode ser considerada "a melhor forma de governo". Vejamos quais seriam as características deste "modelo".

- Um liberalismo político, individualista, não organicista, que defende uma divisão dos poderes, como chek and balance, e admite uma cidadania ampla e não restrita por meio do sufrágio universal e da vontade da maioria, mas que protege também os direitos das minorias.

- Um liberalismo social, que garanta não somente os direitos civis e políticos, mas também os econômicos e sociais; uma concepção da liberdade não somente negativa (não interferência na vida privada dos cidadãos), mas também positiva, que implica em uma intervenção do Estado nos assuntos econômicos e sociais para garantir uma igualdade de oportunidades, as mais amplas possíveis, dentro de uma economia capitalista.

- Uma democracia representativa, que é um elemento elitista: a democracia não é o governo do povo, pelo povo e para o povo, mas da disputa entre várias elites para conquistar o consenso popular. Por isso a qualidade da democracia depende muito da qualidade das suas elites.

- Uma democracia participativa entendendo a participação não como alternativa, mas como complemento necessário à representação, para evitar os perigos da apatia política e do distanciamento da classe política dos cidadãos e permitir uma cidadania ativa que participe da gestão e da fiscalização da coisa pública.

Seriam evitados, assim, os dois extremos de um liberalismo econômico e de uma democracia plebiscitária.

O avanço do neoliberalismo em um contexto de globalização econômica e financeira, é, como havia declarado Bobbio, uma séria ameaça à democracia, porque retira do controle democrático as decisões efetivamente importantes que dizem respeito à economia, que são tomadas em centros de poder e lobbies inacessíveis, que estão acima e além do controle estatal: é a "persistência das oligarquias" e dos "poderes invisíveis", como havia dito nas famosas páginas sobre as "promessas não cumpridas pela democracia" (BOBBIO, 1997, p. 17-40).

O outro extremo é o avanço do populismo, um fenômeno complexo que alia dois componentes: compartilha os pressupostos da democracia direta na sua forma plebiscitária, ou seja, a existência simbólica e mítica de um povo, de uma vontade geral, de um bem comum,

\footnotetext{
${ }^{6}$ É nesse contexto que nasce a discussão sobre as novas ferramentas eletrônicas, que podem ampliar ou manipular os espaços de democracia participativa. Ver JENKINS, 2015.
} 
e, ao mesmo tempo, compartilha do elemento elitista. O líder é chamado mais do que a representar, a defender, personificar, hipostatizar, substancializar este poder popular: a massa popular contra a elite ou a casta política e os "poderes fortes".

O populismo de direita é, hoje, o movimento que mais cresce na Europa, nos Estados Unidos e no Brasil (BENOIST, 2017).

\section{CONCLUSÕES PROVISÓRIAS SOBRE O BRASIL}

"O que define o populismo é a reivindicação de representação exclusiva do povo, e é a relutância em tolerar a oposição ou respeitar a necessidade de instituições independentes que com tamanha frequência põe os populistas em rota de colisão direta com a democracia liberal.

Desse modo, a eleição de Jair Bolsonaro deve ser encarada como o evento mais significativo na história brasileira desde a queda da ditadura militar: pelos próximos anos, o povo terá de lutar pela própria sobrevivência da democracia liberal" (MOUNK, 2019).

O Brasil comemora, em 2020, 32 anos da promulgação da última Constituição; 32 anos de um processo de transição da ditadura militar para a democracia não plenamente consolidado e bastante frágil tanto no que diz respeito às regras formais quanto aos aspectos mais substanciais (TELES-SAFATLE, 2010; TOSI et al., 2014).

Apesar, porém, de todas as dificuldades, houve, na passagem dos governos Itamar Franco, Fernando Henrique Cardoso, Luís Inácio Lula da Silva e Dilma Vana Rousseff, mais continuidades do que rupturas, se considerarmos o respeito das regras do jogo democrático. Foi um dos raros momentos na história brasileira que conseguiu conjugar estabilidade política e conquistas sociais, pelo menos até o impeachment da Presidenta Dilma e o golpe que colocou na presidência Michel Temer, a partir do qual se entrou em um estado de exceção (AGAMBEN, 2004). Com a posse do governo de Jair Bolsonaro, em 2019, a exceção consolidou-se mediante uma aliança entre um populismo autoritário de extrema direita, e um neoliberalismo econômico, que coloca em perigo o processo de democratização que estava se consolidando: menos Estado social e mais Estado penal é o lema do governo.

O Estado Democrático de Direito vive uma tensão permanente entre dois opostos: uma democracia sem direitos (tirania da maioria) ou um direito sem democracia (democracia elitista) (MOUNK, 2018, 2019). Neste momento histórico, a democracia brasileira está submetida simultaneamente a duas ameaças: o populismo e o elitismo.

Olhando na perspectiva da democracia elitista, pode se verificar que a qualidade da classe política brasileira é insuficiente em relação à competência para governar e ao compromisso com as regras do jogo democrático. A corrupção tornou-se um fenômeno sistêmico na política brasileira, e os representantes trazem sempre mais interesses próprios ou de grupos restritos do que os interesses gerais.

A democracia corporativista, criticada por Bobbio em o Futuro da Democracia, como "persistência das oligarquias", é predominante no Brasil: são mais importantes as várias "bancadas" (da bala, do boi, da bíblia) do que os partidos, os quais (com poucas exceções) são mais fisiológicos do que ideológicos. Isto dificulta a "circulação das elites" (como dizia Pareto) 


\section{Humanos e \\ Democracia}

e a sua renovação, e a participação no jogo democrático dos representantes das classes e dos grupos sociais tradicionalmente excluídos, que são sub-representados no Congresso e na política em geral.

Por isso, da agenda política do governo despareceram os temas das desigualdades sexuais, raciais, de gênero e sociais, da luta contra a pobreza, da criação de oportunidades para todos os cidadãos, do papel regulador do Estado sobre o mercado, típicos do liberalismo social, e predominam os temas da agenda liberista.

Há claros sinais de retrocessos com relação a vários aspectos fundamentais da democracia e do respeito às suas regras: a intensa violação dos direitos humanos e a desqualificação dos seus defensores; a politização do Poder Judiciário; a presença massiva das forças armadas (uma instituição autocrática) para exercer funções políticas; a militarização da saúde e da educação; o revisionismo histórico que nega a existência da ditadura militar e o combate às tentativas de resgatar essa memória; o recrudescimento da violência criminal e política; a expansão do crime organizado e das milícias no controle do território e na presença nos aparelhos do Estado; a proposta de ampliar a posse de arma da população civil e de dar "licença para matar" aos policiais; a influência crescente do fundamentalismo religioso nos aparelhos do Estado laico; o ataque à liberdade de cátedra e de expressão dos professores e à autonomia universitária; o ataque aos direitos sociais dos trabalhadores e das classes mais pobres; a conivência com os incêndios na Amazônia e os ataques ao meio ambiente.

O que preocupa também é que o governo está lançando uma "campanha moralista" contra comportamentos morais (em particular sexuais) considerados desviantes, que ameaça a laicidade do Estado; princípio que não se restringe à separação entre Estado e Igreja, mas significa a não interferência do Estado na esfera privada. Em uma concepção liberal, não cabe ao Estado definir e impor estilos e modelos de vida e qual deve ser o comportamento moral dos indivíduos; cada um tem autonomia para isso, tendo como únicos limites aqueles impostos pela lei.

Algo análogo está acontecendo com a "guerra cultural" lançada pelo governo contra as ideologias políticas com as quais discorda: o "marxismo cultural", a pedagogia de Paulo Freire, o "método gramsciano", a "ideologia de gênero", todos reunidos sob o manto do combate ao "comunismo". No contexto atual do debate ideológico brasileiro, comunismo é um conceito vago e indefinido que abrange muitos significados: remete ao "inimigo" histórico dos tempos da ditadura militar e da guerra fria, em um novo contexto totalmente diferente, passados mais de 30 anos da queda do muro de Berlim e do fim da ditadura militar no Brasil, e serve para condenar e perseguir toda e qualquer coisa que possa se assemelhar a um pensamento de esquerda, que ameace os "valores tradicionais": Deus, a pátria, a família e a propriedade.

A estratégia do governo Bolsonaro é clara: governar unicamente para os grupos sociais, políticos e econômicos que o apoiam, e lutar contra os inimigos internos e externos, reais ou imaginários que sejam. Para tanto, precisa manter viva a tensão com os inimigos para garantir o apoio incondicional do "seu povo". O populismo precisa ter sempre um inimigo para lhe declarar a guerra: já Mussolini afirmava: molti nemici molto onore! Nas democracias liberais, lembrando o ensinamento de Karl Popper, no entanto, o competidor não é um inimigo a ser destruído, mas um adversário a ser respeitado e que amanhã pode se tornar governante sem derramamento de sangue. 
Muitas dessas medidas são tomadas com apoio popular, o que confere ao governo uma legitimidade se pensarmos a democracia como mera vontade da maioria, mas levanta preocupações se a pensarmos como respeito dos direitos das minorias e das regras do jogo.

O dilema que enfrenta hoje o Brasil e outros países do mundo pode ser assim expresso utilizando as categorias bobbianas. O Estado Democrático de Direito inclui dois conceitos distintos: a "democracia" e os "direitos", que estão em tensão permanente. Stricto sensu, "democracia" significa simplesmente a regra ou a vontade da maioria. Nesse sentido restrito ela recebeu as críticas mais contundentes, desde os tempos antigos até hoje: Platão a considerava uma forma de anarquia, Aristóteles de demagogia, Kant de despotismo, Tocqueville uma tirania da maioria, Stuart Mill uma tirania da opinião pública sobre as minorias, Ortega y Gasset lamentava a Rebelión de las masas, Hannah Arendt lançava o seu magistral ensaio sobre os totalitarismos de direita e de esquerda e Elias Canetti chamava a atenção para o Poder das massas.

Para evitar o paradoxo ou o oximoro de uma "democracia totalitária", é preciso garantir os direitos de todos e especialmente das minorias, e não somente os direitos civis e políticos, como também os direitos econômicos e sociais, conforme o liberalismo social de Bobbio, tão relevantes em um país com profundas desigualdades como o Brasil.

A democracia brasileira está submetida a um stress text de alta intensidade, e há um perigo real que possa sucumbir. Nesses anos de transição da ditadura à democracia, todavia, foi realizado um enorme trabalho em várias áreas envolvendo milhões de pessoas e milhares de instituições, que nos permitem confiar que as garantias e as liberdades fundamentais sejam respeitadas; que as instituições e a sociedade civil reajam, resistam e funcionem; que as oposições possam agir e atuar sem impedimentos e perseguições; que o governo não se torne um regime que, aos poucos, vai sufocando a democracia; que seja parte de um ciclo, um momento, um contraponto a um período anterior e que se volte a uma alternância de governo; enfim que a exceção não se torne a regra.

Isto vale para o Brasil, mas também para outros países do mundo, onde há uma crise do liberalismo político e um avanço do populismo autoritário e do liberalismo econômico (TOSI, 2019). Parafraseando o título de um famoso livro de Bobbio: Será que a democracia liberal tem ainda um futuro ou estamos assistindo aos últimos capítulos?

O Brasil é um bom laboratório para responder a essa questão.

\section{REFERÊNCIAS}

AGAMBEN, Giorgio. Estado de exceção. São Paulo: Boitempo, 2004.

BARZOTTO, L. F. A democracia plebiscitária. In: BARZOTTO, L. F. A democracia na Constituição. São Leopoldo, RS: Unisinos, 2003. p. 85-130.

BENOIST, Alain de. Populismo. La fine della destra e della sinistra. Bologna: Arianna Editrice, 2017.

BOBBIO, N.; MATTEUCCI, N.; PASQUINO, G. Dicionário de política. Brasília: UnB, 1998.

BOBBIO, N. A democracia dos modernos, comparado à dos antigos (e à dos pósteros). In: BOBBIO, N. Teoria geral da política. A filosofia política e a lição dos clássicos. Rio de Janeiro: Elsevier, 2000a. p. 378-379.

BOBBIO, N. Sobre o liberal-socialismo. In: BOBBIO, N. Teoria geral da política. A filosofia política e a lição dos clássicos. Trad. Daniela Beccaccia Versiani. Rio de Janeiro: Elsevier, 2000b. p. 354-370.

BOBBIO, N. O futuro da democracia. 6. ed. Trad. Marco Aurélio Nogueira. Rio de Janeiro: Paz e Terra, 1997.

BOBBIO, N. Ensaio sobre a ciência política na Itália. Brasília: Editora UnB; São Paulo: Imprensa oficial do Estado, 2002. 


\section{Democracia}

Humanos e

BRENNAN, Jason. Against Democracy. Princeton: Princeton University Press, 2017. (E-book).

CASTELLS, Manuel. Ruptura. A crise da democracia liberal. Rio de Janeiro: Zahar, 2018.

COSTA, Marta Nunes da. Os dilemas de Rousseau. Natureza humana, política e gênero em perspectiva. ljuí: Editora Unijuí, 2017.

COSTA, Pietro; ZOLO, Danilo (org.). O Estado de Direito. História, teoria e crítica. São Paulo: Martins Fontes, 2006. HOLLANDA, Cristina Buarque de. Teoria das elites. Rio de Janeiro: Jorge Zahar, 2011.

HUNTINGTON, Samuel P. A terceira onda. A democratização no final do século XX. São Paulo: Ática, 1994.

JENKINS, Henry. Cultura da conexão: criando valor e significado por meio de mídia propagável. São Paulo: Aleph, 2015.

LACLAU, Ernesto. La ragione populista. Roma-Bari: Laterza, 2008.

LEVITSKY, Steven; ZIBLATT, Daniel. Como as democracias morrem. Tradução Renato Aguiar. Prefácio Jairo Nicolau. Rio de Janeiro: Zahar, 2018.

LEVY, Pierre. Cibercultura. 3. edição. São Paulo, SP: Editora 34, 2010a.

LEVY, Pierre. As tecnologias da inteligência. O futuro do pensamento na era da informática. 2. Edição. São Paulo, SP: Editora 34, 2010b.

LEMOS, André; LEVY, Pierre. O futuro da internet: em direção a uma ciberdemocracia. São Paulo, SP: Editora Paulus, 2010.

LYRA, Rubens P. (org.). Estado e cidadania. De Maquiavel à democracia participativa. João Pessoa: Editora UFPB, 2006.

LYRA, Rubens. P. Ouvidoria pública no Brasil. Modelos em disputa. João Pessoa: Editora da UFPB, 2014.

MERQUIOR, José Guilherme. O liberalismo. Antigo e moderno. Rio de Janeiro: Nova Fronteira, 1991.

MOUFFE, Chantal. O desafio populista. Cadernos IHU Ideias, 2017. Disponível em: http://www.ihuonline.unisinos.br/artigo/6937-o-desafio-populista.

MOUFFE, Chantal. Por um populismo de esquerda. Lisboa: Gradiva, 2019.

MOUNK, Yascha. The People versus democracy. Why our freedom is in danger e how to save it. Cambridge, Massachusetts; London, England: Harvard University Press, 2018. (E-book). Edição brasileira: O povo contra a democracia. Porque nossa liberdade corre perigo e como salvá-la. São Paulo: Companhia das Letras, 2019. (E-book).

NASCIMENTO, Milton Meira do. A farsa da representação política. Ensaios sobre o pensamento político de Rousseau. São Paulo: USP; Discurso Editorial, 2016.

NOZICK, Robert. Anarquia, Estado e utopia. São Paulo: Martins Fontes, 2011.

PANIZZA, Francisco (org.). El populismo como espejo de la democracia. México: Fondo de Cultura Económica, 2009.

PINKER, Steven. Os populistas estão do lado sombrio da História. Entrevista de Juan Martinez Arhens. El País Semanal. 16 jun. 2018a. Disponível em: https://brasil.elpais.com/brasil/2018/06/07/eps/1528366679_426068.html.

PINKER, Steven. $O$ novo iluminismo. Em defesa da razão, da ciência e do humanismo. Trad. Aura Teixeira Motta e Pedro Maia Soares. São Paulo: Companhia das Letras, 2018b. (E-book).

POPPER, Karl. A sociedade aberta e seus inimigos. Belo Horizonte: Editora Itatiaia, 2006. Vols. 1 e 2.

PORTINARO, P. P. El realismo político. Buenos Aires: Nueva Visión, 2007.

PORTINARO, P. P. Introduzione a Bobbio. Roma-Bari: Laterza, 2008. p. 108.

ROUSSEAU, J. J. O contrato Social. São Paulo: Victor Civita, 1983. (coleção Os Pensadores).

RUNCIMAN, David. How Democracy Ends. New York: Basic Books, 2018a.

RUNCIMAN, David. "Talvez este seja o fim do Estado moderno", diz professor de Cambridge. Folha de São Paulo. 21.01.2018. 2018b. Disponível em:https://www1.folha.uol.com.br/ilustrissima/2018/01/1951709-estamos-assistindo-ao-fim-do-estado-moderno-diz-professor-de-cambridge.shtml.

SCHUMPETER, Joseph. Capitalismo, socialismo e democracia. Rio de Janeiro: Editora Fundo de Cultura, 1961.

TELES, Edson; SAFATLE, Vladimir. O que resta da ditadura. E exceção brasileira. São Paulo: Boitempo, 2010.

TOSI, Giuseppe et al. (org.). Justiça de transição. Direito à justiça, à memória e à verdade. João Pessoa: Editora da UFPB, 2014.

TOSI, Giuseppe. A crise do liberalismo político e a ascensão do liberalismo econômico e do populismo autoritário. O caso do Brasil. Teoria Politica, Nuova Serie, Annali IX, p. 227-249, 2019. Disponível em: file:///C:/Users/ GIUSEPPE\%20TOSI/Downloads/tp-827.pdf.

TOSI, Giuseppe; GUIMARÃES, Rubens. Democracia \& elitismo dos antigos e dos modernos. Ensaios. Curitiba: CRV, 2020. 